Counsellia: Jurnal Bimbingan dan Konseling

Volume 11 (1) 56 - 70 Mei 2021

ISSN: 2088-3072 (Print) / 2477-5886 (Online)

DOI: $10.25273 /$ counsellia.v11i18463

Available online at: http://e-journal.unipma.ac.id/index.php/JBK

\title{
Pendekatan REBT Melalui Cyber Counseling untuk Mengatasi Kecemasan di Masa Pandemi COVID-19
}

\author{
Diana Vidya Fakhriyani ${ }^{1}$, Islakhatus Sa'idah ${ }^{2}$, Moh. Ziyadul Haq Annajih ${ }^{3}$ \\ ${ }^{1}$ Fakultas Tarbiyah, IAIN Madura, Pamekasan \\ email korespondensi: dianavidya@iaianmadura.ac.id \\ ${ }^{2}$ Fakultas Tarbiyah, IAIN Madura, Pamekasan \\ ishlakhatus@iainmadura.ac.id \\ ${ }^{3}$ Bimbingan Penyuluhan Islam, STAI Miftahul Ulum, Pamekasan \\ najihas@gmail.com
}

\begin{abstract}
Abstrak
Masalah kecemasan akibat pandemi COVID-19 perlu mendapat perhatian khusus untuk diatasi. Salah satu cara untuk mengatasi masalah tersebut adalah melalui konseling, dengan alternatif pendekatan Rational Emotive Behavor Therapy (REBT). Dalam hal ini, cyber counseling dapat dilakukan karena kondisi sekarang yang mengharuskan untuk physical distancing. Penelitian ini bertujuan untuk mengetahui ciri atau gejala kecemasan akibat pandemi COVID-19, serta kontribusi pendekatan Rational Emotive Behavor Therapy (REBT) melalui cyber counseling untuk mengatasi kecemasan di masa pandemi COVID-19. Penelitian ini menggunakan metode kualitatif, dengan jenis penelitian studi kasus. Purposive sampling digunakan dalam penelitian ini, di mana subyek penelitian adalah konseli yang memiliki masalah kecemasan akibat pandemi. Teknik pengumpulan data yang digunakan adalah wawancara dan kuesioner. Hasil penelitian menunjukkan bahwa Pertama, ciri kecemasan subyek, meliputi aspek fisik, kognitif, emosi, dan perilakunya. Kedua, subyek mampu mengatasi kecemasan yang dialaminya. Ketiga, subyek mampu mengontrol pikiran negatif yang ditimbulkan akibat pandemi. Keempat, subyek dapat lebih menerima kondisi yang terjadi akibat pandemi. Kelima, subyek mampu melakukan kegiatan aktifnya sebagaimana biasanya meskipun terbatas, dengan memperhatikan protokol kesehatan.
\end{abstract}

Kata Kunci: REBT, Cyber counseling, Kecemasan, COVID-19

\section{Abstract}

The problem of anxiety due to the COVID-19 pandemic needs special attention to be solved. One way to solve this problem is through counseling, with REBT as an alternative approach. Cyber counseling can be applied because the condition requires physical distancing. This study aims to determine the characteristics of anxiety due to the COVID19 pandemic, and the contribution of the Rational Emotive Behavor Therapy (REBT) approach through cyber counseling to solve anxiety problems during the COVID-19 pandemic. This research uses qualitative methods, with the research type of case study. Purposive sampling was used in this study, where the subject of research were counselee who had anxiety problems due to the pandemic. The data collection techniques used were interviews and questionnaires. The results showed that first, the characteristics of the subject's anxiety include physical, cognitive, emotional, and behavioral aspects. Second, the subject is able to solve the anxiety problems. Third, the subject is able to control the 
negative thoughts that caused by the pandemic. Fourth, subject can be more accepting of conditions that occur due to pandemics. Fifth, the subject is able to carry out their activities even though they are limited, by paying attention to health protocols.

Keywords: REBT, Cyber counseling, Anxiety, COVID-19

\section{Received ; Accepted ; Published}

Citation: Fakhriyani, Sa'idah, Annajih. (2021). Pendekatan REBT Melalui Cyber Counseling Untuk Mengatasi Kecemasan di Masa Pandemi COVID-19. Counsellia: Jurnal Bimbingan dan Konseling, 11(1), 56 - 70. Doi.org/10.25273/counsellia.v11i18463

\section{(cc) EY-NC-SA}

Copyright $\odot 2021$ Counsellia: Bimbingan dan Konseling

Published by Universitas PGRI Madiun. This work is licensed under the Creative Commons Attribution-NonCommercialShareAlike 4.0 International License

\section{PENDAHULUAN}

Pandemi COVID-19 (Coronavirus Diasease 2019) merupakan masalah global yang hingga saat ini berdampak pada seluruh aspek kehidupan, baik segi ekonomi, sosial, pendidikan, budaya, maupun lingkungan (Heri, 2020). Pandemi berpengaruh terhadap berbagai aspek kehidupan termasuk kesejahteraan psikologis seseorang, di mana kesejahteraan psikologis berkaitan dengan kesehatan mental yaitu kondisi sehat baik fisik maupun psikis, termasuk bebas dari emosi negatif yang dapat menyebabkan kondisi patologis (Fakhriyani, 2019). Emosi negatif tersebut diantaranya adalah kecemasan dan ketakukan berlebih terhadap sesuatu, baik benda maupun peristiwa tertentu (yang belum tentu terjadi), termasuk situasi pandemi COVID-19.

WHO memperingatkan bahwa ketakutan, kecemasan, dan stres akan meningkat karena situasi pandemi COVID-19 (WHO, 2020). Penelitian yang dilakukan oleh Sifat (2020) menunjukkan bahwa COVID-19 menyebabkan kasus bunuh diri, kekerasan dalam rumah tangga, gangguan mental, gangguan depresi, termasuk kecemasan semakin meningkat di seluruh dunia (Sifat, 2020a). Pakar kesehatan memperkirakan bahwa sekitar 300 juta orang menderita gangguan panik dan kecemasan, serta gangguan kesehatan mental bisa berisiko lebih tinggi (Shah, 2020).

Di Indonesia, kelompok usia yang lebih muda cenderung memiliki kecemasan yang lebih tinggi dibandingkan kelompok usia 50 tahun. Berkaitan dengan gender, lakilaki memiliki kemungkinan lebih rendah mengalami gangguan kecemasan dibandingkan perempuan. Selanjutnya, berkaitan dengan tingkat pendidikan, individu dengan tingkat pendidikan menengah ke bawah cenderung memungkinkan mengalami gangguan kecemasan lebih tinggi dibandingkan individu yang berpendidikan tinggi (Megatsari, 2020).

Berbagai cara dilakukan dalam menghadapi pandemi COVID-19 misalnya pembatasan sosial; menjaga jarak; melakukan aktivitas di rumah, bekerja dan belajar dari rumah; penetapan kebijakan PSBB (Pembatasan Sosial Berskala Besar); hingga pemberian vaksin COVID-19. Hal lainnya yang dapat dilakukan untuk menangani dampak psikologis yang ditimbulkan oleh pandemi COVID-19, misalnya mengatasi kecemasan melalui bantuan psikologis untuk mengatasi gejalanya, yakni konseling. Konseling secara langsung tidak memungkinkan untuk dilaksanakan karena kondisi yang mengharuskan untuk psysical distancing, sehingga dapat dilakukan alternative konseling secara virtual, misalnya tele-konseling psikologis, telepsikoterapi, maupun cyber counseling yang bermakna konseling virtual yang berbasis daring (dalam jaringan). 
Dalam rangka mengatasi kecemasan pada masa pandemi COVID-19, sangat dimungkinkan untuk melakukan cyber counseling yang merupakan layanan konseling secara virtual. Cyber Counseling merupakan salah satu model konseling secara virtual atau konseling yang berlangsung melalui bantuan koneksi internet, dengan kondisi konselor dan konseli tidak hadir secara fisik pada ruang dan waktu yang sama (Pasmawati, 2016). Cyber counseling merupakan konseling yang dilakukan antara konselor dan konseli untuk membantu konseli dalam mengembangkan diri dan menyelesaikan masalah yang dialami konseli dengan memanfaatkan koneksi internet sebagai media konseling (Gading, 2020). Penelitian menunjukkan bahwa cyber counseling efektif mengatasi masalah yang dihadapi klien/konseli (Kraus et al., 2010). Layanan konseling secara daring atau cyber counseling memberikan kepuasan yang lebih tinggi pada konseli dibandingkan layanan konseling tatap muka (Dami \& Waluwandja, 2019).

Cyber counseling dapat dilakukan secara individu maupun kelompok, dengan menggunakan berbagai pendekatan psikologi tertentu, misalnya behavior, humanistik, kognitif, ataupun pendekatan lainnya termasuk Rational Emotive Behavior Therapy (REBT). Penelitian menunjukkan bahwa REBT efektif menurunkan kecemasan (Thahir \& Rizkiyani, 2016) (Sari \& Makin, 2018) dan meningkatkan resiliensi pada peserta didik (Noormohamadi et al., 2019). REBT dapat mengatasi kecemasan yang muncul dalam beragam hal, misalnya kecemasan sosial (Aurooj \& Ijaz, 2018), kecemasan dalam menghadapi ujian (Misdeni et al., 2019), kecemasan akibat bullying (Syah, 2020), maupun kecemasan lainnya yang dapat terjadi pada hampir sebagian besar orang. Dapat ditekankan bahwa pendekatan REBT dapat memberikan kontribusi dalam menyelaraskan antara aspek kognitif, respon emosional, dan perilaku, yang berimplikasi dalam mengatasi kecemasan (Paudel, 2020). Lebih lanjut, konseling perilaku kognitif berkontribusi dan dapat dijadikan sebagai alternatif pendekatan dalam koseling untuk mengatasi kecemasan pada masa pandemi COVID-19 (Fitria et al., 2020). REBT mampu membantu seseorang dalam mengatasi kebimbangan pada masa pandemi COVID-19 (Mustaffa, 2020).

REBT merupakan pendekatan yang menekankan pada semua aspek, yakni kognitif (rasional), emosi, dan perilaku, sehingga dapat dijadikan alternatif untuk mengatasi kecemasan di masa pandemi COVID-19. Pendekatan ini dapat diterapkan dalam konseling virtual, yakni cyber counseling. REBT melalui cyber counseling, yang memanfaatkan jaringan internet merupakan layanan konseling yang memungkinkan untuk dilakukan, terutama pada masa pandemi COVID-19 yang mengharuskan masingmasing individu untuk 'jaga jarak' dan kurang memungkinkan untuk bertatap muka.

Melalui cyber counseling, layanan konseling dapat berjalan sebagaimana mestinya, dan di sisi lain juga tetap memperhatikan physical distancing. Dengan demikian, pendekatan REBT melalui cyber counseling penting untuk dilakukan untuk mengatasi kecemasan konseli yang muncul akibat pandemi COVID-19. Penelitian tentang sumbangsih REBT untuk mengatasi kecemasan dan penerapan cyber counseling dalam mereduksi kecemasan telah dilakukan sebelumnya, namun belum ditemukan mengenai kontribusi pendekatan tersebut secara khusus jika pelaksanaannya dilakukan melalui cyber counseling. Maka dari itu, kajian ini akan membahas tentang apakah pendekatan REBT melalui cyber counseling berkontribusi untuk mengatasi kecemasan pada masa pandemi COVID-19.

\section{METODE PENELITIAN}

\section{Rancangan Penelitian}

Penelitian ini menggunakan pendekatan kualitatif, dengan jenis penelitian studi kasus. Menurut Moleong, penelitian kualitatif merupakan penelitian yang bertujuan untuk memahami fenomena mengenai hal-hal yang dialami subyek penelitian, seperti perilaku, motivasi, persepsi, ataupu hal lainnya (Moleong, 2003). Studi kasus merupakan suatu jenis penelitian yang menggambarkan tentang gejala-gejala tertentu secara mendalam dan rinci. Penelitian ini menggunakan pendekatan studi kasus karena dapat memberikan 
beberapa informasi yang baik (Hepper et al., 2008). Meskipun demikian, Hepper berpendapat bahwa pendekatan studi kasus ini tidak memiliki kontrol eksperimental bahkan dapat mengacaukan kesimpulan sementara. Maka dari itu, pendekatan studi kasus ini dilakukan secara mendalam dengan memperhatikan teknik analisis data untuk meminimalisir 'kekacauan kesimpulan sementara' tersebut.

Pendekatan kualitatif digunakan dalam penelitian ini dengan pertimbangan bahwa pendekatan ini mampu megeksplor secara mendalam dan komprehensif tentang masalah kecemasan akibat pandemi COVID-19, serta penyelenggaraan layanan konseling yang dilakukan secara fokus dan sistematis. Lebih lanjut, penggunaan pendekatan studi kasus didasarkan atas tujuan dalam memperoleh gambaran mengenai karakteristik kecemasan yang diakibatkan oleh pandemi COVID-19, serta menggali lebih dalam tentang kontribusi konseling dengan mengunakan pendekatan REBT melalui cyber counseling. Studi kasus digunakan untuk mempelajari kondisi individu secara lengkap dan mendalam dengan tujuan memahami seseorang dengan lebih baik dalam konteks individualitas, dan membantunya dalam perkembangan berikutnya (Winkel, 2005). Studi kasus yang digunakan, mengarah pada penanganan kasus yang secara garis besar melalui langkahlangkah berikut ini: 1) identifikasi kasus; 2) analisis dan diagnosis; 3) prognosis; 4) pemberian treatmen; 5) follow up (tindak lanjut) (Supriyono, 2008).

\section{Sumber Data}

Teknik pengambilan sampel dalam penelitian ini adalah purposive sampling, yang merupakan teknik penentuan sampel dengan tujuan tertentu (Sugiyono, 2016). Subyek dalam penelitian ini adalah konseli yang mengalami kecemasan akibat pandemi COVID-19. Subyek berusia 21 tahun tersebut merupakan seorang mahasiswa semester V pada tahun akademik 2020/2021 di sebuah Perguruan Tinggi Swasta di Pamekasan Madura. Subyek mendaftarkan diri untuk melakukan konseling atas masalah yang dihadapinya, di Laboratorium BKPI (Bimbingan dan Konseling Pendidikan Islam) Institut Agama Islam Negeri (IAIN) Madura.

\section{Teknik Pengumpulan Data}

Pengumpulan data dalam penelitian kualitatif dapat dilakukan dengan beberapa cara, diantanya adalah wawancara, observasi, kuesioner, dan dokumentasi (Sugiyono, 2016). Teknik pengumpulan data yang digunakan dalam penelitian ini adalah wawancara dan kuesioner, yang dilakukan peneliti sebagai konselor kepada konseli sebagai subyek penelitian. Pengumpulan data dilakukan secara daring, yakni melalui WhatsApp (WA), baik chat maupun videocall. Wawancara yang dilakukan adalah dengan mengajukan pertanyaan secara langsung kepada subyek penelitian dan merekam jawaban-jawabannya. Sedangkan kuesioner dilakukan dengan tujuan untuk memperkuat hasil wawancara yang dilakukan. Hasil data kuesioner (angket) dalam penelitian ini tidak berupa angka, tetapi berupa deskripsi. Peneliti juga melakukan pengamatan pada subyek, dengan melihat mimik wajah, intonasi suara, serta bahasa tubuh secara online.

\section{Teknik Analisis Data}

Analisis data merupakan proses mencari data yang diperoleh dari hasil wawancara, serta menyusunnya secara sistematis (Sugiyono, 2016). Analisis data kualitatif berkaitan dengan data berupa kata atau kalimat yang dihasilkan dari objek penelitian serta berkaitan dengan kejadian yang melingkupi sebuah objek penelitian 
(Siyoto \& Sodik, 2015). Adapun analisis data dalam penelitian ini, menggunakan proses sebagai berikut: mereduksi data (data reduction); penyajian data (data display); dan penarikan kesimpulan (conclusion drawing / verification) (Sugiyono, 2016). Pertama, reduksi data, yakni kegiatan menyederhanakan, menggolongkan, memilih data-data yang penting, dan membuang data yang tidak diperlukan, dengan tujuan untuk mendapatkan suatu kesimpulan akhir. Reduksi data yang dilakukan oleh peneliti menghasilkan informasi yang penting dan bermakna, serta mempermudah dalam menarik kesimpulan.

Kedua, penyajian data yakni kegiatan yang dilakukan setelah mereduksi data, dengan menyajikan data dalam bentuk uraian ringkas, bagan, serta hubungan antar data yang berkaitan. Data yang disajikan tersebut bertujuan untuk mempermudah peneliti dalam menganalisis data. Ketiga, penarikan kesimpulan. Kesimpulan akan diperoleh dari hasil analisis data, serta menjadi komponen akhir dalam teknik analisis data. Maka dari itu, kesimpulan tersebut dapat menjawab rumusan masalah yang telah dirumuskan pada awal penelitian dilakukan.

\section{HASIL PENELITIAN DAN PEMBAHASAN \\ Hasil Penelitian \\ Ciri-ciri Kecemasan Subyek Akibat Pandemi COVID-19}

Berdasarkan hasil wawancara yang dilakukan oleh peneliti kepada subyek penelitian sebelum subyek mendapatkan layanan konseling melalu aplikasi WhatsApp yang dilakukan, mendapati bahwa subyek memiliki kecemasan akibat pandemi COVID19 , yang ditandai dengan kecemasan dalam aspek fisik, kognitif, emosi, maupun perilaku. Pertama, pada aspek fisik, beberapa hari terakhir sebelum pelaksanaan konseling, ia merasa jantung berdebar tidak seperti biasanya, dan cenderung merasa sakit kepala.

Kedua, secara kognitif. Aspek kognitif dimaknai dengan nalar atau bagaiamana subyek berpikir tentang suatu hal ataupun kemampuan rasional. Pasa aspek kognitif, subjek mengaku bahwa ia khawatir akan terpapar COVID-19, cemas tentang pandemi yang tak kunjung berakhir akan semakin lama, khawatir tetang pembayaran uang kuliah di semester berikutnya karena perekonomi keluarga yang tidak pasti, serta sulit berkonsentrasi dalam belajar daring yang diselenggarakan di kampusnya.

Ketiga, pada aspek emosi, subyek merasa sulit mengontrol emosinya, yakni mudah tersinggung untuk hal-hal yang sepele misalnya kritik saran dari temannya yang membuatnya tersinggung, di mana sebelumnya subyek merupakan individu yang cenderung terbuka. Keempat, dari segi perilaku, subyek cenderung menghindar dan merasa tidak leluasa dalam beraktivitas dibandingkan sebelum pandemi terjadi, yang mana ia cenderung aktif dalam berbagai kegiatan baik akademik maupun organisasi.

\section{Proses Konseling}

Layanan konseling yang dilakukan peneliti dengan pendekatan REBT (Rational Emotive Behavior Therapy) melaui cyber counseling untuk mengatasi kecemasan yang dihadapi subyek sebagai konseli di masa pandemi COVID-19, dilaksanakan melalui proses membangun rapport, progres hubungan dalam konseling, ekplorasi, diskusi penyelesaian masalah dengan menggunakan pendekatan REBT, serta kesimpulan dan pengakhiran.

Setelah membangun rapport dan eksplorasi masalah yang dihadapi subyek, beralih pada tahapan diskusi dengan pendekatan REBT, terdapat beberapa tahap yang mengacu pada kerangka ABCDE:

a) Tahap pemahaman.

Peneliti mengajak Subyek penelitian untuk memahami dasar dari REBT, yakni bagaimana keyakinan subyek terhubung dan berdampak pada emosi dan perilaku konseli. Tahap ini mengarahkan subyek untuk mengetahui peristiwa yang memunculkan keyakinannya. Hal tertentu, pengalaman, kejadian atau peristiwa, merupakan A (activating events). Keyakinan subyek yang irasional (irB / irrational 
beliefs) terhadap pandemi COVID-19 dapat menimbulkan kecemasan sebagai konsekuensi emosi dan perilaku ( $\mathrm{C} /$ consequences).

b) Tahap pertentangan.

Menentang keyakinan subyek yang irasional. Peneliti melakukan pertentangan atau konfrontasi (D / disputing) terhadap apa yang diyakini subyek. Cara ini efektif untuk membantu subyek mengurangi gangguan emosionalnya, dengan menunjukkan dan menyanggah keyakinan irasional konseli hingga konseli menyerah dan mengakui bahwa apa yang selama ini diyakininya merupakan keyakinan yang irasional. Pertentangan dilakukan dengan melibatkan beberapa langkah berikut ini:

(1) Mendeteksi kepercayaan irasional dan melihat bahwa keyakinan tersebut tidak logis dan tidak realistis.

(2) Memperdebatkan keyakinan irasional ini dan menunjukkan kepada diri siswa bagaimana mereka tidak didukung oleh bukti.

(3) Membedakan antara pemikiran irasional dan pemikiran rasional.

Peneliti mendorong subyek sebagai konseli untuk berpikir rasional. Saat subyek menilai dirinya sudah berpikir rasional, tetapi sebenarnya belum, peneliti dapat terus melakukan pertentangan / konfrontasi terhadap keyakinan yang irasional hingga subyek (konseli) benar-benar berpikir rasional pada situasi pandemi COVID-19 (A) yang tengah dihadapi.

c) Tahap pengaruh pertentangan.

Setelah peneliti melakukan pertenangan atau mengkonfrontasi keyakinan subyek yang irasional, pengaruh (E / effect) yang muncul adalah subyek melepas keyakinannya yang irasional dan memperoleh keyakinan baru yang rasional terhadap pandemi COVID-19.

Berdasarkan wawancara yang dilakukan setelah pelaksanaan layanan konseling dan kuesioner yang diberikan pada subyek, mendapatkan suatu hasil. Hasil yang diperoleh dalam layanan konseling tersebut, bahwasanya dengan pendekatan REBT melalui cyber counseling, subyek mampu mengatasi kecemasan yang dialaminya serta mendapatkan insight untuk menyikapi pandemi COVID-19 secara tepat tanpa dibarengi dengan pemikiran yang irasional. Setelah layanan konseling tersebut dilakukan, peneliti melakukan evaluasi dan tindak lanjut terhadap kegiatan yang telah dilakukan. Beberapa hari setelah layanan konseling dilakukan, subyek penelitian mampu mengatasi kecemasannya. Hal tersebut nampak pada ciri-ciri kecemasan yang mulai cenderung tidak dirasakan subyek, seperti yang dirasakan saat menghadapi kecemasan (sebelum dilakukan layanan konseling).

Ciri-ciri kecemasan yang dialami subyek, seperti sakit kepala (pusing), serta jantung yang berdebar-debar sudah mulai berkurang frekuensinya. Subyek juga mulai tidak merasakan kekhawatiran serta mampu mengontrol pikiran negatif, misalnya mengontrol kecemasan yang berkaitan dengan ketakutan akan terpapar COVID-19, kekhawatiran tentang ketidakmampuan untuk membayar uang kuliah, dan mulai mampu berkonsentrasi pada kegiatan belajarnya. Selain itu, subyek sudah mulai bisa melakukan aktivitas sebagaimana biasanya dengan tetap memperhatikan protokol kesehatan, meskipun tidak dengan leluasa seperti dulu, yakni sebelum adanya pandemi COVID-19. Hasil tersebut diperkuat melalui pengamatan yang dilakukan peneliti kepada subyek, dengan mengamati mimik wajah yang lebih ceria, rangkaian chat dan intonasi suara serta bahasa tubuh yang terlihat lebih semangat, jika dibandingkan sebelum subyek (konseli) mengikuti layanan konseling. 


\section{Pembahasan \\ Kecemasan Akibat COVID-19}

Kecemasan yang dialami oleh subyek meliputi beberapa aspek, yakni fisik, kognitif, emosi, dan perilaku. Kecemasan merupakan kondisi emosi yang dicirikan dengan kekhawatiran dan ketakutan terhadap suatu rangsangan atau kejadian tertentu, dengan beberapa gejala somatis (VandenBos, 2015). Kondisi emosi ini dicirikan dengan keadaan suasana hati negatif yang ditandai dengan gejala fisik dan psikis, seperti ketegangan fisik dan kekhawatiran tentang masa depan (Barlow \& Durand, 2015). Kecemasan merupakan salah satu tanda dari mental illness (Fakhriyani, 2019). Jika masalah kecemasan tersebut tidak dapat ditangani dengan segera dan tepat, maka akan menimbulkan masalah psikologis yang lebih serius.

Lebih lanjut, kecemasan adalah kondisi ketidakberdayaan neurotik, perasaan tidak aman serta tidak matang, kurang mampu menyikapi tuntutan realitas dan lingkungan, merasa kesulitan, dan merasa tertekan dalam kehidupan sehari-harinya (Fakhriyani, 2019). Ketakutan atau kecemasan adalah respon psikofisiologis adaptif tubuh terhadap ancaman pandemi COVID-19. Tingkat kecemasan yang tinggi dapat menyebabkan ketidakmampuan dalam merespon secara rasional dan menunjukkan strategi coping yang maladaptif sehingga menimbulkan gangguan fisik dan psikologis (Paudel, 2020). Kecemasan dapat muncul oleh suatu hal tertentu misalnya kecemasan yang diakibatkan oleh kejadian atau peristiwa tertentu, termasuk kecemasan yang ditimbulkan oleh pandemi COVID-19.

Kecemasan akibat COVID-19 dapat terjadi pada setiap individu, dan hampir sebagian besar dirasakan oleh masyarakat luas. Hal tersebut yang dirasakan oleh subyek yang masih berstatus sebagai pelajar. Subyek yang mengalami kecemasan merupakan mahasiswa di sebuah Perguruan Tinggi. Dengan demikian, kecemasan yang ditimbulkan oleh pandemi COVID-19 tidak hanya dapat terjadi pada pekerja ataupun petugas kesehatan, tetapi juga dapat terjadi pada siapa pun termasuk pelajar. Penelitian membuktikan bahwa mahasiswa menunjukkan kecemasan yang tinggi terhadap COVID19 (Wang \& Zhao, 2020). Selanjutnya, siswa di Bangladesh mengalami depresi dan kecemasan yang meningkat. Sekitar $15 \%$ siswa dilaporkan mengalami depresi sedang, sedangkan 18,1\% menderita kecemasan parah (Islam et al., 2020). Di Indonesia, remaja di masa pandemi COVID-19, 54\% berada pada kategori tinggi (Fitria \& Ifdil, 2020). Sedangkan, pada usia dewasa akhir memiliki tingkat stres dan kecemasan dengan kategori sedang (Ifdil et al., 2020).

Kecemasan yang dihadapi oleh subyek, menimbulkan dampak seperti, sakit kepala, jatung berdebar, ketakutan akan terpapar COVID-19, khawatir jika pandemi ini tidak akan berakhir, khawatir jika tidak mampu membayar uang kuliah, kurang konsentrasi dalam belajar, cenderung tersinggung, menghindar, serta merasa tidak leluasa melakukan aktivitas sehari-hari. Sama halnya dengan penelitian yang dilakukan Ifdil, dkk serta Mahfud dan Gutaman, menyebutkan bahwa pada masa pandemi COVID-19, banyak orang merasa cemas akan beberapa hal, cemas akan terpapar COVID-19, kekhawatiran kehilangan nyawa, kehilangan orang terdekat dan kehilangan pekerjaan (Ifdil et al., 2020), sehingga kecemasan karena takut terpapar, dapat berdampak pada proses pembelajaran mahasiswa serta serta kecemasan akan terganggunya ekonomi keluarga (Mahfud \& Gumantan, 2020).

Ciri-ciri kecemasan yang dihadapi oleh subyek, merupakan kecemasan yang diakibatkan oleh COVID-19, yang sebelumnya tidak dirasakan oleh subyek. Kecemasan dapat menimbulkan dampak pada aspek berikut ini (Ghufron \& Risnawita, 2014):

(1) Aspek Fisik, yang ditandai dengan sakit kepala, berkeringat, menimbulkan rasa mual, grogi, mulut kering, dan sebagainya.

(2) Aspek emosional, yang ditandai dengan timbulnya rasa panik dan rasa takut.

(3) Aspek mental, yang ditandai dengan munculnya gangguan perhatian dan memori, khawatir, tidak jernih dalam berpikir, dan bingung. 
Berdasarkan ciri-ciri kecemasan yang dialami oleh subyek yang telah dipaparkan sebelumnya, dapat diketahui bahwa subyek mengalami kecemasan akibat pandemi COVID-19. Pandemi COVID-19 mengakibatkan berbagai hal, termasuk kecemasan yang meningkat di berbagai belahan dunia (Sifat, 2020b; Asmunds_on____Taylor,_202020). Di Cina, prevalensi depresi dan kecemasan pada wanita dan petugas kesehatan garda depan, lebih tinggi dibandingkan dengan populasi Cina pada umumnya (Bareeqa et al., 2020).

\section{Pendekatan REBT Melalui Cyber Counseling}

Konseling dapat dilakukan bagi subyek yang mengalami kecemasan akibat pandemi COVID-19. Pemberitaan dalam kabar berita dan media sosial dapat mengakibatkan meningkatnya kecemasan terhadap COVID-19. Peran konselor, psikolog, dan psikiater benar-benar dibutuhkan untuk mengurangi stres dan kecemasan yang diakibatkan oleh pandemi COVID-19 (Dong \& Bouey, 2020). Layanan konseling yang diberikan kepada subyek (konseli), merupakan alternatif cara untuk mengatasi masalah kecemasan yang dihadapi oleh subyek. Konseling dapat dimaknai sebagai proses pemberian bantuan psikologis oleh konselor kepada konseli, dengan tujuan untuk membantu konseli agar konseli mampu memahami diri sendiri dan lingkungannya, sehingga konseli berada pada kondisi kehidupan yang lebih efektif (Kirana, 2019). Layanan konseling dilakukan untuk mengatasi kecemasan yang muncul akibat pandemi COVID-19, yang dapat diatasi dengan berbagai pendekatan psikologi, diantaranya adalah pendekatan Rational Emotive Behavior Therapy (REBT).

Pendekatan REBT meyakini bahwa terdapat interaksi secara terus menerus antara aktivitas berpikir, merasakan, dan berperilaku. Ketiganya berpengaruh satu sama lainnya (Corey, 2012). REBT berasumsi bahwa ketika seseorang dihadapkan pada peristiwa yang merugikan, maka akan timbul keyakinan yang irasional sehingga menghasilkan perasaan disfungsional yang berakibat pada perilaku maladaptif. Di sisi lain, keyakinan rasional menghasilkan emosi fungsional dan perilaku adaptif (Bernard \& Dryden, 2019). Berdasarkan pendekatan REBT mengamini bahwa kejadian atau peristiwa akan berpengaruh terhadap kognisi, emosi, dan perilaku, di mana ketiganya terintegrasi dalam diri seseorang.

Layanan konseling dengan pendekatan REBT diberikan kepada subyek, karena REBT mampu menurunkan tingkat kecemasan individu. Beberapa penelitian menunjukkan bahwa REBT efektif untuk mengatasi kecemasan. REBT berpengaruh terhadap penurunan kecemasan pada remaja korban bullying (Syah, 2020). REBT mampu mengatasi kecemasan dengan menyeimbangkan antara pola pikir, emosi, dan perilaku (Paudel, 2020). Pendekatan REBT yang diterapkan dalam layanan konseling, untuk mengatasi kecemasan akibat COVID-19, tidak memungkinkan untuk dilakukan secara tatap muka. Maka dari itu, proses konseling dilakukan secara virtual dengan tetap memperhatikan hal-hal yang berkaitan dengan konseling, misalnya, asas konseling, keterampilan dalam konseling, tahapan, serta hal-hal tentang pendekatan REBT.

Layanan konseling yang diberikan kepada subyek merupakan konseling dengan menggunakan pendekatan REBT melalui cyber counseling, yang tidak mengurangi tujuan dari konseling itu sendiri, yakni untuk mengatasi kecemasan akibat pandemik COVID-19. Penelitian menunjukan bahwa cyber counseling dapat mereduksi (menurunkan) kecemasan (Syam, 2020). Tidak dapat dipungkiri, bahwa di dalam proses pemberian bantuan oleh konselor kepada konseli, terjadi interaksi antara konselor-konseli. Interaksi antara konselor dan konseli tidak hanya terjadi dalam hubungan tatap muka, namun juga dapat dilakukan secara virtual melalui jaringan internet (Petrus \& Sudibyo, 2017). 
Sebagai konselor yang profesional, seorang konselor harus mampu melakukan pelayanan konseling baik secara tatap muka maupun secara online (Nurfarhanah et al., 2019). Penting untuk memperhatikan profesionalitas konselor dan efektifitas pelaksanaan cyber counseling, yang merupakan konseling yang dilakukan secara daring atau virtual.

Konseling yang diberikan kepada subyek, dengan menggunakan pendekatan REBT melalui cyber counseling, pada hakikatnya sama dengan konseling secara langsung, hanya berbeda media yakni online atau offline. Cyber counseling adalah strategi konseling virtual yang dilakukan melalui bantuan jaringan internet, baik dalam bentuk situs web, email, facebook, konferensi video, maupun melalui sosial media lainnya (Budianto et al., 2019). Cyber counseling menjelaskan bahwa dalam proses konseling, konselor dan konseli tidak secara bersamaan hadir secara fisik, ruang dan waktu yang sama. Cyber counseling efektif untuk diterapkan dalam proses konseling

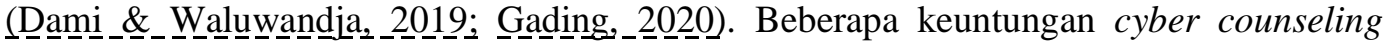
adalah: mudah, nyaman, tidak ada batasan jarak \& lokasi, privasi, dan aman (Mejah et al., 2019).

Kegiatan konseling yang diberikan oleh peneliti sebagai konselor, dilakukan melaui aplikasi WhatsApp baik melalui chat maupun videocall. Cyber counseling dilakukan, mengingat efektivitas yang sama yang dapat diperoleh seperti kegiatan konseling secara tatap muka pada umumnya. Di masa pandemi COVID-19 yang dihadapi saat ini, cyber counseling menjadi pilihan efektif yang dapat dilakukan untuk mengatasi permasalahan psikologis, seperti stres dan kecemasan. Untuk mengatasi kecemasan dapat dilakukan pendampingan psikologis secara online (Wulandari \& Hidayat, 2020). Maka dari itu, cyber counseling dapat dilaksanakan guna meminimalisir kecemasan di masa pandemi COVID-19, dengan tetap memperhatikan keterbatasan dalam pelaksanaannya, misalnya kurangnya respon non-verbal yang dapat diberikan konselor saat proses konseling seperti ekspresi wajah dan bahasa tubuh, tidak dapat mengontrol perilakuperilaku tertentu yang dapat melemahkan dinamika konseling (Petrus \& Sudibyo, 2017).

Peneliti melakukan konseling dengan menggunakan pendekatan REBT melalui cyber counseling, di mana peneliti sebagai konselor cyber counseling memiliki posisi unik di dalam proses layanan konseling. Meskipun dalam keadaan terpisah, konselor diharapkan tetap dapat membaca gejala psikologis konseli yang muncul saat layanan secara virtual. Konselor harus memiliki keterampilan sebagai konselor cyber counseling, baik dari segi kemampuan menciptakan kenyamanan dan kebebasan psikologis, genuine, unconditional positive regard, empatik, maupun media yang digunakan. Selain itu, konselor harus mampu menghindari faktor-faktor yang dapat menghambat pelaksanaan cyber counseling. Selanjutnya, efektifitas cyber counseling dapat dibuktikan dengan adanya perubahan perilaku konseli serta penerimaan konseli terhadap konselor.

Konseling yang dilakukan peneliti dengan menggunakan pendekatan REBT melalui cyber counseling, dapat dilihat pada proses berikut ini: 


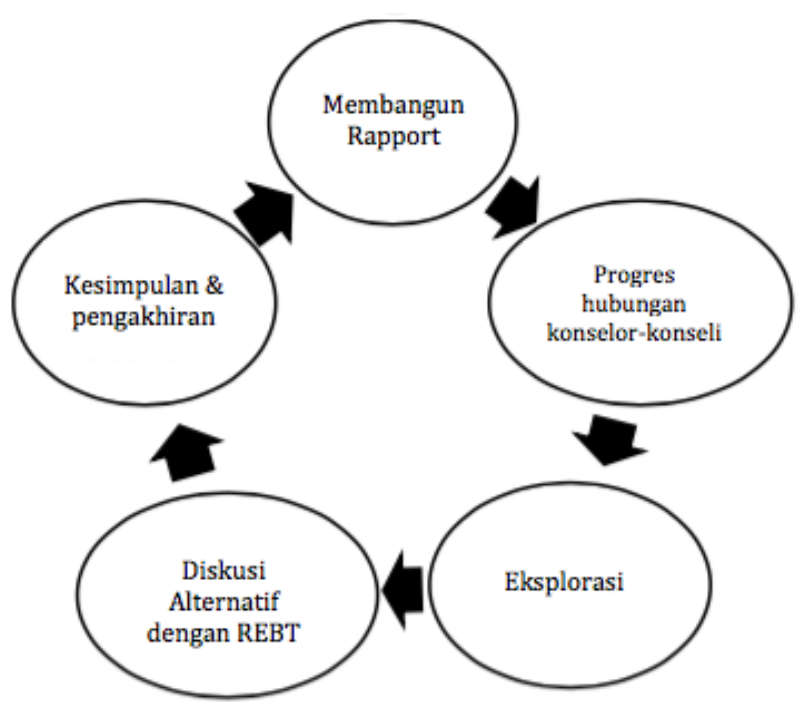

Gambar: Tahapan Proses Konseling REBT melalui Cyber Counseling

Gambar tersebut menunjukkan proses konseling dengan pendekatan REBT, yang dilakukan melaui cyber counseling. Sama halnya dengan layanan konseling pada umumnya, yakni pada pelaksanaannya, cyber counseling diawali dengan membangun rapport, sehingga subyek merasa nyaman dan aman dalam mengeksplorasi permasalahan yang dihadapinya. Selanjutnya, melakukan diskusi dengan pendekatan yang telah dipilih sebelumnya yakni pendekatan Rational Emotive Behavior Therapy (REBT) hingga pada tahap kesimpulan dan pengakhiran.

Peneliti menggunakan kerangka ABC dalam pendekatan REBT (Paudel, 2020; (Fauziah et al., 2020), yaitu:
$\mathrm{A}=$ Activating events, pengalaman atau peristiwa yang terjadi
$\mathrm{B}=$ Beliefs, keyakinan terhadap $\mathrm{A}$
$\mathrm{irB}=$ irrational Beliefs (keyakinan yang irasional)
$\mathrm{rB}=$ rational Beliefs (keyakinan yang rasional)
$\mathrm{C}=$ Consequence, konsekuensi atau reaksi emosional terhadap $\mathrm{B}$
$\mathrm{D}=$ Disputing, mempertentangkan / membantah / mengkonfrontasi irB
$\mathrm{E}=$ Effect, pengaruh atas D

Kerangka $\mathrm{ABCD}$ tersebut, selanjutnya diimplementasikan dalam layanan konseling individu melalui cyber counseling yang dilakukan oleh konselor pada konseli dalam rangka membantu konseli untuk menyelesaian problematika yang sedang dihadapi konseli. Albert Ellis merumuskan model ABC untuk Terapi Perilaku Emosi Rasional. Model $\mathrm{ABC}$ dan premis dasarnya dapat digunakan dalam berbagai bentuk intervensi psikoterapi, termasuk dalam mengatasi kecemasan. REBT memberikan pemahaman dan kesadaran tentang hubungan antara kognisi atau pemikiran, respon emosional dan perilaku (Paudel, 2020).

Terdapat beberapa tahap yang mengacu pada kerangka ABCDE, yaitu tahap pemahaman, tahap pertentangan, dan tahap pengaruh pertentangan. Pertama, tahap pemahaman yang berkaitan dengan bagaimana subyek memahami tentang keyakinannya yang dapat berdampak pada emosi maupun perilaku subyek. Keyakinan subyek yang 
irasional terhadap pandemi COVID-19 dapat mengakibatkan munculnya kecemasan sebagai konsekuensi emosi atapun perilaku (C / consequences).

$K e d u a$, tahap pertentangan, yakni bagaimana peneliti sebagai konselor melakukan pertentangan atau konfrontasi (disputing) terhadap keyakinan subyek yang irasional. Tahap ini merupakan usaha untuk membantu subyek dalam mengurangi kecemasan yang dirasakannya, yang dilakukan dengan cara menyanggah keyakinan subyek yang irasional. Peneliti mengkonfrontasi keyakinan subyek yang irasional sampai subyek menyadari bahwa keyakikannya terhadap pandemi COVID-19 selama ini, merupakan keyakinan yang tidak tepat.

Ketiga, tahap pengaruh. Pengaruh pertentangan yang merupakan pengaruh yang muncul setelah tahap konfrontasi dilakukan. Hasilnya adalah subyek melepaskan keyakinannya yang irasional atau tidak tepat dan mendapatkan keyakinan baru yang tepat serta lebih rasional tentang pandemi COVID-19. Pada tahap ini subyek telah meyakini bahwa pandemi COVID-19 memang ada dan setiap individu memiliki kemungkinan untuk terpapar, namun hal tersebut dapat diminimalisir atau dihindari, misalnya dengan berusaha mematuhi protokol kesehatan sesuai intruksi pemerintah. Selain itu, subyek menuturkan bahwa apa yang selama ini diyakininya, yakni tentang ketakutannya akan terpapar COVID-19, tidak benar-benar terjadi padanya.

Penerapan pendekatan REBT melalui cyber counseling memberikan dampak bagi subyek yakni, subyek mampu mengatasi kecemasan yang dialaminya, subyek mampu mengontrol pikiran negatif yang ditimbulkan akibat pandemi COVID-19, serta subyek dapat lebih dapat menerima baik kondisi pandemi COVID-19 yang terjadi maupun akibat yang ditimbulkannya. Hal tersebut dapat diketahui melalui perubahan subyek, baik fisik, kognitif, sosial, maupun perilaku.

Ciri fisik seperti frekuensi sakit kepala dan jantung yang berdeba-debar tidak seperti biasanya, mulai berkurang dan merasa lebih rileks. Selanjutnya, subyek juga tidak merasakan kekhawatiran dan mampu mengontrol pemikiran negatif, yang ditunjukkan dengan konsentrasi subyek yang mulai kembali baik dalam kegiatan belajarnya serta mampu melakukan kegiatan aktifnya sebagaimana biasanya meskipun tidak leluasa dibandingkan sebelum adanya pandemi COVID-19. Selain itu, respon yang ditunjukkan oleh subyek menunjukkan bahwa kecemasan yang dialaminya dapat diatasi. Respon tersebut ditandai dengan mimi wajah yang lebih cerah ceria, chat di WhatsApp dan intonasi suara serta bahasa tubuh yang tampak lebih semangat dan antusias, dibandingkan saat pertama kali sebelum mengikuti konseling. Dengan demikian pendekatan REBT melalui cyber counseling mampu memberikan kontribusi untuk mengatasi kecemasan yang dialami oleh subyek akibat pandemi COVID-19.

\section{SIMPULAN}

Krisis psikologis, diantaranya yaitu kecemasan yang ditimbulkan oleh pandemi COVID-19 penting untuk diatasi guna menjaga kesehatan mental. Dalam rangka mengatasi kecemasan, dapat dilakukan layanan konseling psikologis baik yang diselenggarakan secara individu ataupun kelompok, dengan prosedur secara tatap muka ataupun secara virtual. Pada layanan konseling yang telah dilakukan, peneliti menggunakan pendekatan REBT sebagai alternatif cara untuk mengatasi kecemasan yang dialami subyek. REBT diterapkan dengan pertimbangan bahwa dalam penelitian terdahulu, REBT mampu mengatasi kecemasan. Pertimbangan lainnya terkait pelaksanaan konseling, yakni tidak dilakukan secara tatap muka sebagaimana biasanya karena kondisi saat ini yang lebih memungkinkan untuk melakukan cyber counseling. Terlebih, penelitian sebelumnya menunjukkan bahwa cyber counseling efektif untuk mengatasi kecemasan. Maka dari itu, peneliti melakukan konseling dengan menggunakan pendekatan REBT melalui cyber counseling untuk mengetahui ciri-ciri kecemasan akibat pandemi COVID-19, serta kontribusi pendekatan REBT melalui cyber counseling dalam mengatasi kecemasan di masa pandemi COVID-19. 
Berdasarkan hasil penelitian dan pembahasan, dapat disimpulkan bahwa ciri atau karakteristik kecemasan yang dialami subyek akibat pandemi COVID-19 meliputi aspek fisik, kognitif, emosi, dan perilakunya. Ciri-ciri tersebut yaitu cenderung sering mengalami sakit kepala dan jantung yang bedebar-debar, tidak sebagaimana biasanya. Hal lain yang dirasakan subyek yaitu subyek khawatir akan terpapar COVID-19, subyek merasa cemas pada pandemi yang akan terjadi lebih lama lagi, subyek khawatir tidak mampu membayar biaya kuliah akibat ekonomi yang tidak menentu, sulit berkonsentrasi dalam belajar, sulit mengontrol emosi, menarik diri, cenderung menghindar, dan tidak leluasa dalam aktivitasnya. Lebih lanjut, pelaksanaan konseling dengan pendekatan REBT melalui cyber counseling memberikan kontribusi terhadap masalah yang dialami subyek. Ciri-ciri kecemasan yang disampaikan sebelumnya, dapat diatasi oleh subyek, subyek mampu mengontrol pikiran-pikirannya yang negatif, subyek dapat menerima adanya pandemi COVID-19 dengan terbuka, dan subyek sudah mampu melakukan aktivitasnya meskipun dengan terbatas, namun tetap memperhatikan protokol kesehatan sebagai bentuk antisipasi diri terhadap penyebaran COVID-19.

Selanjutnya, penelitian ini berimpikasi pada pengembangan ilmu (secara teoritik) maupun praktik layanan ke depannya. Secara teoritik, penelitian ini dapat menambah khazanah ke-ilmuan tentang bimbingan konseling terutama tentang pendekatan REBT melalui cyber counseling dan masalah kecemasan, namun demikian perlu dilakukan pengembangan dalam rangka menambah wawasan tentang ke-BK-an tersebut. Berkaitan dengan masalah kecemasan, perlu diketahui bahwa kecemasan merupakan emosi yang normal (lumrah) terjadi pada setiap individu. Namun, kecemasan yang berlebihan dapat menimbulkan patologis yang dapat berdampak pada kehidupan, misalnya tidak lagi mampu melakukan aktivitas sehari-hari sebagaimana biasanya, tidak mampu berpikir rasional, depresi, dan sebagainya. Maka dari itu, berpikir positif, berpikir rasional, psikoedukasi, dan hal positif lainnya, hendaknya selalu dilakukan untuk mengatasi masalah kecemasan terutama di masa pandemi COVID-19 yang dapat berdampak pada masalah psikologis yang lebih serius. Dalam praktiknya, penelitian ini dapat dijadikan acuan dalam kerangka layanan konseling baik mengenai pendekatan REBT melalui cyber counseling, maupun tentang kecemasan.

\section{UCAPAN TERIMAKASIH}

Terlaksananya penelitian ini serta rampungnya naskah, tidak terlepas dari dukungan banyak pihak. Mewakili rasa bersyukur, Kami mengucapkan terimakasih kepada IAIN Madura, khususnya Lab. BKPI IAIN Madura sebagai wadah penyelenggaraan konseling serta pihak-pihak yang berkontribusi dalam penelitian ini.

\section{DAFTAR PUSTAKA}

Asmundson, G. J. G., \& Taylor, S. (2020). Coronaphobia: Fear and the 2019-nCoV outbreak. Journal of Anxiety Disorders, 70, 102196. https://doi.org/10.1016/j.janxdis.2020.102196

Aurooj, A., \& Ijaz, T. (2018). Rational Emotive Behavior Therapy Effective for the Features of Social Anxiety among University Students. 6.

Bareeqa, S. B., Ahmed, S. I., Samar, S. S., Yasin, W., Zehra, S., Monese, G. M., \& Gouthro, R. V. (2020). Prevalence of depression, anxiety and stress in china during COVID-19 pandemic: A systematic review with meta-analysis. The 
International Journal of Psychiatry in Medicine, 0091217420978005. https://doi.org/10.1177/0091217420978005

Barlow, D. H., \& Durand, V. M. (2015). Abnormal Psychology_ An Integrative Approach. Cengage Learning. www.cengage.com/global

Bernard, M. E., \& Dryden, W. (2019). Advances in REBT.

Budianto, A. E., Hidayah, N., \& Aziz, A. (2019). Aplikasi Cyber Counseling Dengan Mengoptimalkan Whatsapp Berbasis Komputasi Mobile. KURAWAL Jurnal Teknologi, Informasi dan Industri, 2(2), 182-193. https://jurnal.machung.ac.id/index.php/kurawal

Corey, G. (2012). Theory \& Praktice of Group Counseling (Eighth Edition). Brook/Cole Cengage Learning.

Dami, Z. A., \& Waluwandja, P. A. (2019). Counselee Satisfaction in Face-to-Face and Cyber-Counseling Approach to Help Cyber-Bullying Victims In The Era Of Industrial Revolutions 4.0: Comparative Analysis. European Journal of Education Studies, 6(4), 232-245. https://doi.org/10.5281/zenodo.3344908

Dong, L., \& Bouey, J. (2020). Public Mental Health Crisis during COVID-19 Pandemic, China-Volume 26, Number 7-July 2020-Emerging Infectious Diseases journal—CDC. https://doi.org/10.3201/eid2607.200407

Fakhriyani, D. V. (2019). Kesehatan Mental. Duta Media Publishing.

Fauziah, Neviyarni, Karneli, Y., \& Netrawati. (2020). Modifikasi Konseling Kelompok Untuk Siswa Dengan Pendekatan Rational Emotive Behavior Therapy (REBT) di Tengah Pandemi Covid-19. Consilium: Berkala Kajian Konseling Dan Ilmu Keagamaan, 7(2), 52-59. http://jurnal.uinsu.ac.id/index.php/consilium

Fitria, L., \& Ifdil, I. (2020). Kecemasan remaja pada masa pandemi Covid -19. Jurnal EDUCATIO: Jurnal Pendidikan Indonesia, 6(1), 1-4-4. https://doi.org/10.29210/120202592

Fitria, L., Neviyarni, Netrawati, \& Karneli, Y. (2020). Cognitive Behavior Therapy Counseling Untuk Mengatasi Anxiety Dalam Masa Pandemi Covid-19. ALIRSYAD, $10(1), \quad 23-29 . \quad \mathrm{http} / / / j u r n a l . u i n s u . a c . i d / i n d e x . p h p / a l-$ irsyad/article/view/7651

Gading, I. K. (2020). The Development of Cyber Counseling as a Counseling Service Model for High School Students in the Digital Age. JPI (Jurnal Pendidikan Indonesia), 9(2), 301. https://doi.org/10.23887/jpi-undiksha.v9i2.25469

Ghufron, M. N., \& Risnawita, S. (2014). Teori-teori Psikologi. Arruzz Media.

Hepper, P. P., Kivlighan, D. M., \& Wampold, B. E. (2008). Research Design In Counseling (Third). Thomson Brooks/Cole.

Heri, H. (2020, December 21). Atasi Dampak Covid-19, Pengamat: Bidang Kesehatan, Ekonomi dan Hukum Harus Diperioritaskan. Nusantarapos.co.id. https://nusantarapos.co.id/berita/61980/21/12/2020/atasi-dampak-covid-19pengamat-bidang-kesehatan-ekonomi-dan-hukum-harus-diperioritaskan/

Ifdil, I., Yuca, V., \& Yendi, F. M. (2020). Stress and anxiety among late adulthood in Indonesia during COVID-19 outbreak. JPPI (Jurnal Penelitian Pendidikan Indonesia), 6(2). https://doi.org/10.29210/02020612

Islam, Md. A., Barna, S. D., Raihan, H., Khan, Md. N. A., \& Hossain, Md. T. (2020). Depression and anxiety among university students during the COVID-19 pandemic in Bangladesh: A web-based cross-sectional survey. PLOS ONE, 15(8), e0238162. https://doi.org/10.1371/journal.pone.0238162

Kirana, D. L. (2019). Cybercounseling Sebagai Salah Satu Model Perkembangan Konseling Bagi Generasi Milenial. Al-Tazkiah, 8(1), 51-63. https://doi.org/10.20414/altazkiah.v8i1.1101

Kraus, R., Stricker, G., \& Speyer, C. (Eds.). (2010). Online counseling: A handbook for mental health professionals (2nd ed). Academic Press. 
Mahfud, I., \& Gumantan, A. (2020). Survey Of Student Anxiety Levels During The Covid-19 Pandemic. Jp.jok (Jurnal Pendidikan Jasmani, Olahraga dan Kesehatan), 4(1), 86-97. https://doi.org/10.33503/jp.jok.v4i1.1103

Megatsari, H. (2020). Gangguan Kecemasan Masyarakat Indonesia Selama Pandemi COVID-19. Unair News. http://news.unair.ac.id/2020/10/23/gangguankecemasan-masyarakat-indonesia-selama-pandemi-covid-19/

Mejah, H., Bakar, A. Y. A., \& Amat, S. (2019). Online Counseling as an Alternative of New Millennial Helping Services. International Journal of Academic Research in Business and Social Sciences, 9(9), Pages 40-54. https://doi.org/10.6007/IJARBSS/v9-i9/6267

Misdeni, M., Syahniar, S., \& Marjohan, M. (2019). The Effectiveness of Rational Emotive Behavior Therapy Approach Using a Group Setting to Overcome Anxiety of Students Facing Examinations. International Journal of Research in Counseling and Education, 3(2), 82-88. https://doi.org/10.24036/0064za0002

Moleong, L. J. (2003). Metode Penelitian Kualitatif. Remaja Rosdakarya,.

Mustaffa, N. (2020). Mengatasi Kebimbangan Semasa Pandemik Covid-19 Dengan Pendekatan Teori Rational Emotive Behaviour Theraphy (REBT). Malaysian Journal of Social Sciences and Humanities (MJSSH), 5, 10-16. https://doi.org/10.47405/mjssh.v5i11.553

Noormohamadi, S. M., Arefi, M., Afshaini, K., \& Kakabaraee, K. (2019). The effect of rational-emotive behavior therapy on anxiety and resilience in students. International Journal of Adolescent Medicine and Health. https://doi.org/10.1515/ijamh-2019-0099

Nurfarhanah, Afdal, Zikra, Z., \& Andriani, W. (2019). Analysis of the Causes of Cyberbullying: Preliminary Studies on Guidance and Counseling Media. 300306, 7. http://creativecommons.org/licenses/by-nc/4.0/

Pasmawati, H. (2016). Cyber Counseling Sebagai Metode Pengembangan Layanan Konseling di Era Global. Syi 'ar, 16(1), 12.

Paudel, D. (2020). ABC framework of fear of COVID-19 for psychotherapeutic intervention in Nepal: A review [Preprint]. PsyArXiv. https://doi.org/10.31234/osf.io/9sj4a

Petrus, J., \& Sudibyo, H. (2017). Kajian Konseptual Layanan Cyberconseling. Konselor, 6(1), 6. https://doi.org/10.24036/02017616724-0-00

Sari, C., \& Makin. (2018). Efektivitas Konseling Kelompok Menggunakan Pendekatan Rational Emotive Behavior Therapy (REBT) Untuk Mengurangi Kecemasan Peserta Didik SMP IT Masjid Syuhadak Yogyakarta. G-Couns: Jurnal Bimbingan Dan Konseling, 3(1), Article 1. https://doi.org/10.31316/g.couns.v3i1.91

Shah, P. (2020). Psychological well-being: A challenge in Covid-19 regime. https://www.thefinancialexpress.com.bd/views/psychological-well-being-achallenge-in-covid-19-regime-1586186005

Sifat, R. I. (2020a). Impact of the COVID-19 pandemic on domestic violence in Bangladesh. Asian Journal of Psychiatry, 53, 102393. https://doi.org/10.1016/j.ajp.2020.102393

Sifat, R. I. (2020b). COVID-19 pandemic: Mental stress, depression, anxiety among the university students in Bangladesh. International Journal of Social Psychiatry, 002076402096599. https://doi.org/10.1177/0020764020965995

Siyoto, S., \& Sodik, A. (2015). Dasar Metodologi Penelitian. Literasi Media Publishing. Sugiyono. (2016). Metode Penelitian. Alfabeta. 
Supriyono. (2008). Studi Kasus Bimbingan dan Konseling. CV. Nieuw Setapak.

Syah, M. E. (2020). Rational Emotional Behavior Therapy (REBT) to Reduce Anxiety Bullying Victims in Adolescents. Journal of Family Sciences, 5(1), 36-46. https://doi.org/10.29244/jfs.5.1.36-46

Syam, S. (2020). Reducing Student Learning Anxiety Through Cyber Counseling-Based Individual Counseling Services. Akademika: Jurnal Teknologi Pendidikan, 9(02), 105-113. https://doi.org/10.34005/akademika.v9i02.1048

Thahir, A., \& Rizkiyani, D. (2016). Pengaruh Konseling Rational Emotif Behavioral Therapy (REBT) dalam Mengurangi Kecemasan Peserta Didik Kelas VIII SMP Gajah Mada Bandar Lampung. KONSELI: Jurnal Bimbingan Dan Konseling (E-Journal), 3(2), 197-206. https://doi.org/10.24042/kons.v3i2.560

VandenBos, G. R. (Ed.). (2015). APA dictionary of psychology (2nd ed.). American Psychological Association. https://doi.org/10.1037/14646-000

Wang, C., \& Zhao, H. (2020). The Impact of COVID-19 on Anxiety in Chinese University Students. Frontiers in Psychology, 11. https://doi.org/10.3389/fpsyg.2020.01168

WHO. (2020). Mental health and psycho- logical resilience during the COVID-19 pandemic. https:// www.euro.who.int/en/health-topics/health-emergencies/ coronavirus-covid-19/news/news/2020/3/mental-health- and-psychologicalresilience-during-the-covid-19-pandemic

Winkel, W. S. (2005). Bimbingan dan Konseling di Institusi Pendidikan. Media Abadi.

Wulandari, P., \& Hidayat, R. (2020). General Anxiety Disorder-Related Coronavirus Disease-19 Outbreak in Indonesia: A Case Report. Open Access Macedonian Journal of Medical Sciences, 8(T1), 36-38. https://doi.org/10.3889/oamjms.2020.4762

\section{PROFIL SINGKAT}

Diana Vidya Fakhriyani adalah Dosen Program Studi Bimbingan dan Konseling Pendidikan Islam, Fakultas Tarbiyah, IAIN Madura. Saat ini, aktif dalam projek penelitian di bidang Psikologi dan Konseling.

Ishlakhatus Sa'idah adalah Dosen Program Studi Bimbingan dan Konseling Pendidikan Islam, Fakultas Tarbiyah, IAIN Madura. Ia juga merupakan reviewer dari jurnal Edu Consilium: Jurnal Bimbingan dan Konseling Pendidikan Islam. Selain itu ia aktif dalam projek penelitian pada pengembangan media BK.

Moh. Ziyadul Haq Annajih adalah Dosen Program Studi Bimbingan Penyuluhan Islam, STAI Miftahul Ulum Pamekasan Madura. Ia aktif dalam projek penelitian dan pengembangan di bidang Bimbingan dan Konseling. 